\title{
Effectiveness of Agricultural Extension Methodsin Conflict Resolution Among Pastoralists Communities in Adamawa State, Nigeria
}

\author{
Ibrahim A.A. ${ }^{1}$, Peter, M. B ${ }^{2}$.,Zainab .I.A. ${ }^{3}$. and Dahiru. $\mathrm{H}^{4}$ \\ ${ }^{1 \& 2}$ Department of Agricultural Extension Services, Faculty of Agriculture, University of Maiduguri, Maiduguri, \\ Nigeria. ${ }^{3}$ Department of Marketing, Ramat Polytechnique, Maiduguri, Borno State, Nigeria. ${ }^{4}$ Department of \\ Agricultural Economics and Extension, School of Agriculture and Agricultural Technology Yola, ModiboAdama \\ University of Technology Yola.
}

\begin{abstract}
This study was conducted to assess the effects of agricultural Extension Methods used in conflict resolutions among pastoralists. A multi - stage proportional random sampling techniques was used for selection of 160 respondents used for the study. The result revealed that $59.38 \%$ of respondents claimed they have used truce in their conflict resolution. About $10.63 \%$ of the respondents had used tolerance in their conflict resolutions. About $42.5 \%$ of the respondents claimed that, farm and home visit extension method use truce to resolveconflict effectively.A significance test was carried out, which reveals that it is significant to use extension methods of farm and home visits, as $t-v a l u e, 0.01$ coefficient of $G_{p}=0.16$ at $1 \%$ level of significant. The test also indicates that extension contact used during meetings had its $t$-value as 1.42 , coefficient 676.65 and $P$ value 0.04 and significant at $1 \%$ level. Meaning that agro - pastoralists increased levels of group meeting lead to increase in conflict resolution probably because of group participation through meetings tends to increase ideas in favour of conflict resolutions. The characterization of agricultural extension methods used for conflict resolutions were embodied in social - economic realities of the agro - pastoralists. Even when the extension workers had demonstrated higher level of effectiveness (56.8\%) in conflict resolution through their usual contacts with agro - pastoralists, conflict still exists between the agro - pastoralists.Based on the findings, it was recommended that; government should increase the number of well-trained extension workers with capacity for agro - pastoralists conflict resolutions and use of farm and home visits for effective conflict resolutionsby extension workers.
\end{abstract}

Key words: Extension Methods, Conflict Resolutions, Pastoralist Communities

\section{Introduction}

It is a social reality that considerable efforts had been made throughout the world to identify conflict, sources, effects, and appropriate methods of resolutions; (Pur et al., 2006). Similar observation was madeby World Bank (2003) who reported that, conflict which is expressed kind of struggle between two independent parties are increasingly becoming a constraint towards developing agriculture in many developing nations. Conflict therefore is conceived as a situation in which humans could be exposed to a number of tensions that generate struggle over space and time,sometimes modified into violence. In Nigeria, crop and animal producers had co - existed over the yearsin spite of their several conflict situations arising from time to time.

For farmers to take decision, for possession or lack of possession of the scarce resources, extension workers who are in close contact with these agro - pastoralists should assist in wise choice of decision making among various alternatives.

In a nutshell extension education is an educational process that uses varieties of extension methods designed to helps farmers improve their living standards through educational procedures. Extension methods could be used for understanding the best ways to handle the farmers, identifyingconflicts and solutions so as to improve their standards of living, (Obibuaku, 1983).

According to FAO, (2003) a work plan for 1999 was distributed to extension agents in which the role of extension agents in pastoralist communities were enumerated as follows:

i. Education of pastoralist both young and adults in the area of cooperative organization and management;

ii. Animal and crop production in a reduced conflict operating on acceptable conflict resolutions;

iii. Animal health and crop production education; and,

iv. Basic and functional literacy and numeracy aimed at reducing conflict in agro - pastoralist communities.

In order to ensure that pastoralists participate in the implementation of the extension education programme, the extension agents have to address the problems through the use of extension methods for the increased 
livestock production. Therefore,Extension education is a process directed through extension methods to bring about changes in what pastoralists know changes and how they react favorablyto conflict situations.

An effort to resolve conflict among agro - pastoralists requiresan effective extension method as through an increased contact with pastoralist communities. Despite these contact between the extension workers and pastoralists, specific effectsof extension methods on conflict resolutions are yet to be understood which had necessitated this study with the following objectives.

\section{Objective of the study}

The main objective of the study is to assess the effectiveness of Agricultural Extension Methods used for Conflict Resolution among Pastoralists Communities in Adamawa State, Nigeria. The specific objectives are to:

1. Identify the types of conflict resolutions in the study area

2. Identify the effectiveness of extension methods used by extension workers for conflict resolutions.

3. Determine the effect of extension methods used by extension workers before and after extension contact with the agro - pastoralists.

4. Assess the relationship between the extension methods and conflict resolutions of the agro pastoralists.

\subsection{Study area}

\section{Methodology}

The study area is Adamawa state, located in the North - Eastern part of Nigeria between latitude $8 \mathrm{~N}$ and $11 \mathrm{~N}$ and longitudes $11.5 \mathrm{E}$ and $13.5 \mathrm{~N}$ to the east of the state in the republic of Cameroun, while Taraba, Borno and Gombe states share border with Adamawa state to the south - west, north and north - west respectively. The population of Adamawa state according to the 2006 census figure, stood at 3.7 million people (NPC, 2006) the total area of the state is approximately $38,741 \mathrm{~km}^{2}$ with about $226.04 \mathrm{~km}^{2}$ been arable (crop production recommendation for Adamawa state, 1996).

The data for the study area obtained through primary source (use of questions) and secondary sources (Journals, records of ministry of agriculture and ADPS). A multi stage random sampling technique was employed to select respondents for data collection for the study area. The first stage was the random selection of two (2) Local Government Areas from each of the four Agricultural Development Project (ADP) administrative zones, making a total of 8 Local Government Areas. In the second stage three villages were randomly selected from each of the eight Local Government Areas, making a total of 24 villages. The third stage involves random and proportionate selection of 160 agro pastoralists from the 24 villages for the study.

\subsection{Analytical procedure}

The data obtained was analyzed using descriptive statistics (percentages and frequencies) and inferential lstatistics (logit model)

The logit model was used to simulate the effect of stochastic perturbations in extension methods for conflict resolutions on agro-pastoralists. Increased frequency of extension methods used for conflict resolutions the model calculates the level of conflict resolved among the respondents.

The model is adapted from the study of Ehrlich et al. (1990) and was modified to capture the scope of the study. $\mathrm{N}_{\mathrm{t}+1}=(1+0.01 \times \Delta \mathrm{N}) \times \mathrm{N}_{\mathrm{t}} \ldots \ldots . .(1)$

Where $\mathrm{N}=$ number of responses, $\Delta \mathrm{N}$ is the increase or decrease conflict resolutions used through extension methods.

$\mathrm{G}_{\mathrm{P}, t+1}=(1+0.01 \times \Delta \mathrm{G}) \times \mathrm{G}_{\mathrm{P}, \mathrm{t}}$

$\mathrm{G}_{\mathrm{nf}, \mathrm{t}+1}=\mathrm{G}_{\mathrm{P}, \mathrm{t}+1}+0.01 \times \mathrm{V} \mathrm{x} \mathrm{G} \mathrm{G}_{\mathrm{P}, \mathrm{t}+1}$

$\mathrm{G}_{\mathrm{a}, \mathrm{t}+1}=\mathrm{G}_{\mathrm{nf}, \mathrm{t}+1}+0.01 \times \mathrm{m} \mathrm{x} \mathrm{G} \mathrm{nfft}_{\mathrm{t}+}$

Where;

$\mathrm{G}_{\mathrm{p}}=$ potential conflict resolutions

$\Delta=$ increased or decreased in conflict resolutions

$\mathrm{G}_{\mathrm{nf}}=$ Potential extension methods used for conflicts resolutions

$\mathrm{V}=$ number of times selected randomly for extension method used

$\mathrm{G}_{\mathrm{a}}=$ Actual conflict resolution within the year of crop/livestock season

$\mathrm{D}_{\mathrm{e}}=$ Extension method used

Conflict resolution $(C)$ is calculated as $\mathrm{C}=(0.33 \mathrm{~T}) \times \mathrm{N}$.

According to CBN (2012), this model is commonly used in decision involving choices as to accept extension methods for conflict resolution or rejection of extension methods used to resolved conflicts, hence the choice of multinomial logit model (MNL) was also found appropriately used in individual or group decisions in a conflict situation. 
The explanatory variable used in the multinomial logit model (MNL) was hypothesized as respondents poor in level of conflicts which reduces productivity; extension contact brings conflict resolutions consequently increased extension methods. These extension methods were specified as follows; as contained in equation ...(1-4).

$\mathrm{X} 1=$ Farm and home visit

$\mathrm{X} 2=$ Telephone call

$\mathrm{X} 3=$ Group discussion

$\mathrm{X} 4=$ Meeting

X5 = Radio listening

$\mathrm{X} 6=$ Television programme

$\mathrm{X} 7=$ Farm demonstration

\section{Results and Discussion}

The distributions of respondents according to the types of conflict resolutions used in the study area were presented in table 1 . The result revealed that $59.38 \%$ of the respondents indicated that they used truce method in resolving their conflicts. About $7.5 \%$ of the respondents used displacement method. Furthermore, $3.75 \%$ of the respondents used super ordination method, $18.75 \%$ of the respondents used compromise method while $10.63 \%$ of the respondents used tolerance in resolving their conflicts in the study area. This implies that, there were several methods used in conflict resolution in the study area.

Table 2 indicates the opinion of respondents on the effectiveness of extension methods used by the extension workers. Majority of the respondents $56.8 \%$ said farm and home visit was used for conflict resolution through extension contact and was highly effective. This finding is in agreement with (Olowu and Yahaya, 1998) who reported that farm and home visits were rated by farmers as the highest ranking preference because of its ability to transfer clearly improved farm massages to farmers. Educational campaign was ranked $2^{\text {nd }}$ by $53.1 \%$ of the respondents as the highly effective extension methods used for conflict resolutions. This result was not unexpected since most of the educational campaigns were carried out based on conflict and conflict resolutions status in the area by the extension workers who had close contacts with the respondents. The extension methods that were not effective (36.8\%)were ranked least (6) for radio and television. This result may not be unconnected to high cost, poor massages transmission, poor power supply and low area of radio coverage in a remote agro - pastoralist's communities.

Table 2 indicates the distribution of respondent's ratings on the effectiveness of extension methods used for conflict resolutions. A highly effective method was assigned a score of 1 fairly effective extension methods take a score of 2 and not effective method takes a score of 3 . Meaning that, the lower the number of respondent's responses to extension methods used the score is also low and that the ranking were also expected to be higher.These agree with Hussain (1998) who note that crops damaged by livestock were among the main causes of tension. The scores were assigned to effectiveness; very effective (3) effective (2) and not effective (1) maximum score 360 . The score were later ranked to analyze the effects of extension methods on conflict resolutions.

Table 3 shows that, extension methods of farm and home visit had the maximum score of 360 and was ranked 1 as highly effective, followed by the educational campaign methods with the score of 355 ranked 2 . The farm and home visits of extension method ranked first could be due to face to face contact between the extension worker under a friendly atmosphere to understand the conflict situation of the respondents and offers appropriate solutions to resolve the conflict. Similarly, educational campaign provide opportunities for large attendance, it is a forum where respondents discuss their problems with others during and after the educational campaign. These could be one of the reason why educational campaign had 355 score and was ranked 2 . Radio and television have disadvantage of high cost and difficult to maintain due to poor electric power supply in many communities, had a score of 335 and was ranked 6 .

Entries in table 3 reveals that, $75 \%$ of the respondents said farm demonstrations before and after extension contact had the difference on conflict resolutions and was ranked 7 with a mean of 17.71 . This implies that agro - pastoralists were affected through farm demonstration on conflict resolutions when they were contacted by extension workers, before their first contact and after the last year cropping season. Farm and home visits were ranked $1^{\text {st }}$ with mean 3.14 as opined by $57.5 \%$ of the respondents. This was followed by telephone calls ranked $2^{\text {nd }}$ with mean of 6.00 as stated by $26.2 \%$ of the respondents. Respondentsexpressed their opinion difference exists before extension contact when they used telephone calls after they had contact.

Therefore, all the respondents had opined that before using the extension methods and after the last year crop and livestock season, respondents had experienced some level of differences on conflict resolutions, (see table 4.

Table 4 shows the computed $t$ - value of 0.01 calculated coefficient for $9.16 G_{p}$. Potential of extension methods as farm and Home visits for conflict resolutions among agro - pastoralists was not significant probably because there were few agricultural extension workers who insufficiently perform the roles of farm and home 
visitswhen compared to the ratio of agro - pastoralists. This means that extension workers were insufficient to cater for extension messages needed by agro - pastoralists through farm and home visits. Conflict resolutions messagesshould be significantto the number of agro - pastoralists through farm and home visit methods. The calculated $t$ - value of 1.42 calculated coefficients $(676.65)$ for $G_{p}$ potential meetings was significant at $1 \%$ level viewed in relation to the computed $\mathrm{P}$ - value $(0.04)$. A probable explanation on meetings had a significant effects at $1 \%$ level of significance was that, the agro - pastoralists might have acquiredtheir abilities to resolved conflicts through shared ideas during meetings. This means that,the more increase in meetings, the more agro pastoralists were able to resolve their conflicts.

Similarly, the computed $\mathrm{t}$ - value $(0.82)$ for farm demonstration with the coefficient 42.96 in relation to proportion 0.01 was found to be significant. This can be explained due to the fact that, farm demonstration is an extension method that practically serves as an eye opener to agro - pastoralists to see the reasons for conflict resolutions. This is usually carried out through the involvement of the agro - pastoralists during demonstration processes. When there is increase in the demonstration on conflict resolution by the extension workers to agro pastoralists, it results,in the correspondence increase in the level of conflict resolutions. This entails that agro pastoralists take decision in favour of conflict resolutions, when extension workers used more of demonstration methods for conflict resolutions during contacts with the agro - pastoralists.

\section{Conclusion and recommendations}

Conflict resolution process in agro - pastoralists' ecological zones is extensive, sporadic and could lead to progressive positive social change in the developing social communities of agro - ecological zone. It is a concept of far reaching and has critical implications for the extension methods used by extension workers to bring about positive change on conflict resolution in the agro - pastoralists ecological zone. Based on these findings the following policy recommendations were made.

1. Government should increase the number of well-trained extension workers to cater effectively for conflict resolutions agro - pastoralists.

2. Extension workers should use farm and home visitsfor positive change in conflict resolutions.

3. Setting up of Reconciliation Committees that Would looked into the remote causes of conflicts and means of conflict resolutions.

4. Organize conflict and conflict resolutions educational campaign for peace keeping and rapid change in agro - pastoralist's productivity.

Table 1: Distribution of respondents according to types of conflict resolution used.

\begin{tabular}{lll}
\hline Types & Frequency & Percentage (\%) \\
\hline Truce & 95 & 59.38 \\
Displacement & 12 & 7.5 \\
Super Ordination & 6 & 3.75 \\
Compromise & 30 & 18.75 \\
Tolerance & 17 & 10.63 \\
Total & 160 & 100 \\
Mean & 2.14 & \\
Standard Deviation & 1.53 & \\
\hline
\end{tabular}

Source: Field survey data, 2013

Table 2: Distribution of the respondents according to effective extension methods used by extension worker for conflict resolutions

\begin{tabular}{|c|c|c|c|c|c|c|}
\hline Variable & $\begin{array}{l}\text { Highly effective } \\
\text { Frequency }(\%)\end{array}$ & $\begin{array}{l}\text { Fairly } \\
\text { Frequency (\%) }\end{array}$ & $\begin{array}{l}\text { Not effective } \\
\text { Frequency }(\%)\end{array}$ & $\begin{array}{l}\text { Total } \\
\text { score }\end{array}$ & mean & Rank \\
\hline Farm demonstration & $80(50.0)$ & $43(20.8)$ & $37(23.1)$ & 350 & & 3 \\
\hline Farm \& home visit & $91(56.8)$ & $37(25.1)$ & $32(20.0)$ & 360 & & 1 \\
\hline Educational campaign & $85(53.1)$ & $24(15.0)$ & $51(31.8)$ & 355 & & 2 \\
\hline Radio/Television & $63(39.3)$ & $38(38.7)$ & $59(36.8)$ & 335 & & 6 \\
\hline Group discussion & $76(47.5)$ & $27(16.8)$ & $57(35.8)$ & 340 & & 5 \\
\hline Meetings & $78(48.7)$ & $46(28.7)$ & $34(21.2)$ & 345 & & 4 \\
\hline
\end{tabular}

Source: Field survey data, 2013

Table 3: Distribution of respondents according to effects of extension methods used before and after extension

\begin{tabular}{|c|c|c|c|c|c|}
\hline Extension methods & $\begin{array}{l}\text { Before } \\
\text { Frequency (\%) }\end{array}$ & $\begin{array}{l}\text { After } \\
\text { Frequency (\%) }\end{array}$ & $\begin{array}{l}\text { Difference } \\
\text { Frequency }(\%)\end{array}$ & Mean & Rank \\
\hline Farm \& home visit & $68(42.5)$ & $92(57.5)$ & $24(15.0)$ & 3.14 & 1 \\
\hline Telephone calls & $59(36.8)$ & $101(63.1)$ & $42(26.2)$ & 6.00 & 2 \\
\hline Group discussion & $56(35.0)$ & $104(65.0)$ & $48(30.0)$ & 7.89 & 3 \\
\hline
\end{tabular}




\begin{tabular}{|c|c|c|c|c|c|}
\hline Meetings & $42(26.2)$ & $118(73.7)$ & $76(47.5)$ & 10.86 & 4 \\
\hline Radio & $40(25.0)$ & $120(75.0)$ & $80(50.0)$ & 11.42 & 5 \\
\hline Television & $28(17.5)$ & $132(81.5)$ & $104(65.0)$ & 14.84 & 6 \\
\hline Farm demonstrations & $18(11.2)$ & $142(88.7)$ & $124(77.5)$ & 17.71 & 7 \\
\hline
\end{tabular}

Source: Field survey data, 2013

Table 4: Computed Multinomial Model relationship the Explanatory Effects of Extension Methods on Income

\begin{tabular}{lllll}
\hline & & & \\
\hline variable & Coefficient & t-ratio & P-proportion & Decision \\
\hline Constant & -531442.402 & -1.471 & 0.233 & - \\
Farm \& Home visit & 9.16 & 0.01 & 0.07 & $\mathrm{Ns}$ \\
Telephone call & 31.04 & 1.18 & 0.04 & $\mathrm{~S}$ \\
Group discussion & 2074.00 & 0.93 & 0.24 & $\mathrm{Ns}$ \\
Meeting & 676.65 & 1.42 & 0.04 & $\mathrm{~S}$ \\
Radio listening & 224.75 & 0.29 & 0.77 & $\mathrm{Ns}$ \\
Television & 112.32 & 0.77 & 0.62 & $\mathrm{Ns}$ \\
Farm demonstration & 42.96 & 0.82 & 0.01 & $\mathrm{~S}$ \\
\hline
\end{tabular}

Source: Computed from field survey data, 2013

\section{REFERENCES}

[1]. Anonymous, L.O. (2001).Memorandum on Farmer - Pastoralist Clashes in Nigeria.Federal Development of Livestock and Pest Control Services.

[2]. Ani A.O; Ibrahim, Abdul Abu and Gwary, M.M, (1999).Effective Research-Extension -Farmers linkage for Sustainable Agricultural Development in Nigeria.African Journal of Agricultural Research. African Center for Agricultural Resources, Addis Ababa and Development Africa Consortium, Port - Harcourt, Vol.1, No.2, pp 47 - 52.

[3]. Beeler, S. (2006). Post Harvest Physiological Deterioration of Cassava; Proceedings of $12^{\text {th }}$ Symposiums of International Society of Tropical wood crops Held at Tsukulu Japan Pp $10-16$

[4]. CBN (2011).Effect of Global Climate Change on Nigerian Agriculture : am Empirical Analysis. Journal of Applied Statistics Volume 2 No. 1 Pp $31-50$

[5]. Dixon, J. Gulliver, A. and Gibbon, D. (2001). Global Farming Systems Study: Challenges and Priorities to 2030 Synthesis and Global Overview. FAO, Rome, Italy 98 pp.

[6]. Ehrlich, P.R. Daily, G.C., Ehrlich, A.H., Matson, P. and Vitousek, P.(1989). Global change and carrying capacity: Implications for life on earth. In Global change and our common future. Washington D.C.: National Academy Press.

[7]. Federal Agricultural Coordinating Unit (1999). Farmer - Pastoralist Conflict in the core states of the National Fadama Development Project.

[8]. Food and Agricultural Organization (2003).Statistical Data basis, Rome Italy.

[9]. Fermandez - Rivera, S, Okike, I, Manyong, V, Williams, T.O Kruska, R. L. and Hammel, R. (2000). Securing land for Herders in Niger, Conflict at Lake Chad.

[10]. N.P.C (2006).National Population Census, Federal Republic of Nigeria; Official Gazette.Vol. 94, Lagos.

[11]. Obibuaku, L.O.(1983). A manual for agricultural Extension as Strategy for agricultural transformation in Nigeria

[12]. Ogumbameru, B.O. (2001).Evaluation of Extension Manpower Training Programme by Jigawa Agricultural and Rural Development Authority.Journal of Agricultural and Agricultural Society of Nigeria. AESON Vol. $4-6$ Pp $150-160$

[13]. Olaleye, O.I (2010).Livestock Farmers awareness, access and benefit of Veterinary Extension Services in Southern Nigeria. Livestock Research for Rural Development, Vol. 16 Act 39 http//www/rrd.org/rrg/ss/1639/httn.

[14]. Olowu, T. A. and Yahaya, M.K (1983). Nigerian Journalist Attitude towards Coverage of Rural Development News, Nigerian Journal of Rural Extension and Development 2 \& 3 Pp39 - 48

[15]. Pur, J.T. Gaya, I.M. and Bensiheik, K. (2006).Causes of Farmer-Pastoralist Conflict in Borno State. Journal of Agricultural Extension Vol.9, PP.87 - 94

[16]. World Bank (2003). Agricultural Knowledge and Information System http//wb/n0018worldbank.opendocument. 